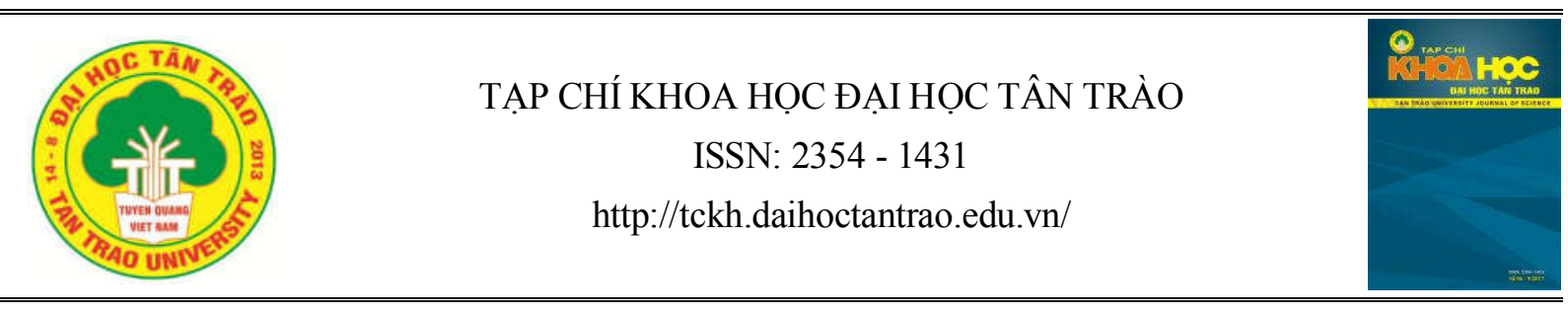

\title{
Nghiên cứu ứng dụng, sử dụng chế phẩm nấm ký sinh Metarhizium anisopliae phòng trừ rầy nâu, rầy lưng trắng hại lúa tại Tuyên Quang
}

\author{
Phạm Thị Mai Trang ${ }^{a^{*}}$, Nguyễn Thị Hoài Anh ${ }^{a}$, Nguyễn Thị Thu Hiền ${ }^{a}$ \\ ${ }^{a}$ Trưòng Đại học Tân Trào \\ *Email: maitrang.bvtvtq@gmail.com
}

\section{Thông tin bài viết}

Ngày nhận bài:

$15 / 5 / 2019$

Ngày duyệt đăng:

$10 / 6 / 2019$

\section{Tù khóa:}

Nấm ký sinh Metarhizium sp; rầy nâu; rầy lung trắng.

\section{Tóm tắt}

Rầy nâu, rầy lưng trắng (rầy) được coi là một trong những loài sâu hại chính trên cây lúa ở trên thế giới nói chung và Việt Nam nói riêng. Rầy không những gây hại trực tiếp làm giảm năng suất và phẩm chất lúa, mà còn là môi giới truyền virus gây bệnh trên lúa. Do vậy để phòng trừ rầy người nông dân đã sử dụng rất nhiều loại thuốc hoá học (BVTV), tuy nhiên thuốc BVTV trừ rầy thường là thuốc có độc tính cao, chậm phân hủy có thể giữ tác dụng rất lâu trong sản phẩm. Để thay thế dần việc sử dụng thuốc hóa học trong sản xuất nông nghiệp, gần đây các nhà khoa học đã nghiên cứu đã thành công việc sử dụng nấm Metarhizium anisopliae (M. anisopliae) trong phòng trừ sau hại nói chung và phòng trừ rầy hại lúa nói riêng. Kết quả thử nghiệm tại Tuyên Quang năm 2015, 2016 cho thấy: Chế phẩm M. anisopliae ở liều lượng $8 \mathrm{~kg}$ /ha có hiệu lực trừ rầy nâu, rầy lưng trắng hại lúa, hiệu lực 10 ngày sau xử lý đạt từ đến $61,68-65,16 \%$, vừa không ảnh hưởng đến sự sinh trưởng, phát triển, năng suất, chất lượng của cây lúa, vừa không ảnh hưởng đến môi trường sinh thái.

\section{1. Đặt vấn đề}

Rầy nâu, rầy lưng trắng được coi là một trong những loài sâu hại chính ở hầu hết các vùng sản xuất lúa trọng điểm trên thế giới. Tại Việt Nam từ những năm đầu thập niên 90 đến nay rầy luôn là đối tượng dịch hại chính trên lúa, diện tích lúa nhiễm rầy trung bình mỗi năm của các tỉnh phía Bắc là trên 400 nghìn ha, trong đó nhiễm nặng trên 50 nghìn ha và mất trắng khoảng từ 300 - 500 ha mỗi năm. Rầy không những gây hại trực tiếp làm giảm năng suất và phẩm chất lúa, mà còn là môi giới truyền virus gây bệnh trên lúa: như rầy nâu truyền virus gây bệnh vàng lùn, lùn xoắn lá, rầy lung trắng, rầy nâu nhỏ truyền virus gây bệnh lùn sọc đen,...Để phòng trừ rầy hại lúa người nông dân đã sử dụng rất nhiều loại thuốc hoá học, tuy nhiên thuốc BVTV trừ rầy thường là thuốc có độc tính cao, chậm phân hủy có thể giữ tác dụng rất lâu trong sản phẩm.

Đặc biệt nghiêm trọng hơn là việc lạm dụng thuốc BVTV của người dân dẫn tới việc bùng phát dịch hại mới, diệt trừ các loài thiên địch, để lại dư lượng thuốc BVTV trong nông sản cũng như đất đai, môi trường, ảnh hưởng đến sức khỏe con người vật nuôi cũng như môi trường sinh thái. Để thay thế dần việc sử dụng thuốc hóa học trong sản xuất nông nghiệp, gần đây các nhà khoa học đã nghiên cứu đã thành công trong việc sử dụng nấm gây bệnh cho côn trùng để phòng trị các loại côn trùng và sâu hại cây trồng, điển hình như nấm $M$. anisopliae và Beauveria bassiana đã được ứng dụng trong phòng trừ mối nhà, sâu khoang hại cải xanh, sâu hại đậu tương và đậu xanh, rầy mềm và các loài sâu hại lúa.

Để góp phần vào việc hướng tới nền nông nghiệp sạch, bền vững, việc nghiên cứu ứng dụng sử dụng chế phẩm nấm $M$. anisopliae trong phòng trừ dịch hại góp phần giảm thiểu ảnh hưởng thuốc BVTV tới môi trường sống của con người, sinh vật có ích khác là vấn đề cần thiết. Tại Việt Nam, năm 2006 Cục Bảo vệ thực vật đã có văn bản công nhận việc sử dụng nấm M. anisopliae trừ rầy nâu, rầy lưng trắng hại lúa là tiến 
bộ kỹ thuật mới tại một số tỉnh khu vực phía Nam, hiện nay một số tỉnh phía Bắc đã và đang thực nghiệm. Để có cơ sở áp dụng mở rộng việc sử dụng chế phẩm nấm $M$. anisopliae trong phòng trừ rầy hại lúa tại Tuyên Quang chúng tôi đã thực hiện nghiên cứu ứng dụng, sử dụng chế phẩm nấm ký sinh Metarhizium $s p$ phòng trừ rầy nâu, rầy lưng trắng hại lúa.

2. Thời gian, địa điểm, vật liệu, nội dung và phương pháp nghiên cứu

\subsection{Thời gian và địa điểm}

- Thời gian: Từ tháng 7/2014 đến tháng 7/2016.

- Địa điểm: Tại các vùng trồng lúa huyện Sơn Dương, Yên Sơn, Thành phố Tuyên Quang, tỉnh Tuyên Quang.

\subsection{Vật liệu nghiên cúu}

Rầy nâu, rầy lung trắng, nấm $M$. anisopliae

\subsection{Nội dung nghiên cúu}

Nội dung 1. Nghiên cứu diễn biến quần thể rầy nâu, rầy lưng trắng

Nội dung 2. Thử nghiệm so sánh hiệu quả của nấm M. anisopliae trong phòng trừ rầy nâu, rầy lưng trắng và đánh giá hiệu quả phòng trừ.

\subsection{Phưong pháp nghiên cúu}

\subsubsection{Bố trí thi nghiệm}

Bố trí thí nghiệm theo quy chuẩn kỹ thuật quốc gia QCVN 01-29:2010/BNNPTPT về khảo nghiệm trên đồng ruộng hiệu lực của thuốc trừ rầy hại lúa:

\begin{tabular}{|c|l|r|}
\hline CT & \multicolumn{1}{|c|}{ Thuốc thử nghiệm } & \multicolumn{1}{c|}{ Liều lượng } \\
\hline I & Chế phấm M.anisopliae & $8 \mathrm{~kg}$ \\
\hline II & BPDYGAN 5.4EC & 0,1 lít \\
\hline III & EMAAICI 50WG & $0,3 \mathrm{~kg}$ \\
\hline IV & Đối chứng & Không phun \\
\hline
\end{tabular}

\subsubsection{Phuoong pháp nghiên cúu}

Nội dung 1: Nghiên cúu diễn biến quần thể rầy nâu, rầy lung trắng

- Theo phương pháp điều tra phát hiện dịch hại cây trồng tại Quy chuẩn kỹ thuật quốc gia QCVN 01-38: 2010/BNNPTNT.

- Thời gian điều tra định kỳ 7 ngày/ lần; Điều tra bổ sung theo tuyến khi mật độ cao: 7 ngày/ lần

- Chỉ tiêu theo dõi: tổng số rầy nâu, rầy lưng trắng/ điểm điều tra

- Dụng cụ: khay inox 20x20x5cm, thước $1 \mathrm{~m}$, dầu madut, kính núp cầm tay, kinh núp soi nổi, túi bắt mẫu, ống hút rầy ...

Nội dung 2: Thủ nghiệm so sánh hiệu quả của nấm M. anisopliae trong phòng trù̀ rầy nâu, rầy lung trắng và đánh giá ảnh hưởng của chế phẩm đến cây lúa.
- Dụng cụ: chế phẩm nấm M.anisopliae hàm lượng 2,5-4,0 x $10^{9}$ bào tử/gam, thuốc trừ rầy BPDYGAN $5.4 \mathrm{EC}$, thuốc trừ rầy EMAAICI $50 \mathrm{WG}$. Khay inox 20x20x5, túi đựng mẫu, thước 1m, dầu madut, kính núp cầm tay, kinh núp soi nổi, dây nilon, bảng công thức thí nghiệm, bình bơm thuốc BVTV ...

- Thuốc được phun khi lúa vừa bị nhiễm rầy mật độ rầy cám khoảng 20-40 con/khóm ( từ 750 $1.500 \mathrm{con} / \mathrm{m}^{2}$ )

- Lượng nước: 600 1/ha.

- Dụng cụ: bình bơm điện đeo vai.

+ Diện tích ô thí nghiệm: $300 \mathrm{~m}^{2} / \mathrm{o}$ công thức;

- Chỉ tiêu theo dõi và phương pháp điều tra:

+ Mật độ rầy trước xử lý $1,3,7,10$ ngày sau xử lý. Dùng khay kích thước $20 \times 20 \mathrm{~cm}$ tráng dầu để xác định mật độ rầy. Mỗi ô điều tra 10 điểm không cố định trên 2 đường chéo góc, mỗi điểm điều tra 4 khóm. Nghiêng khay sát với thân lúa $45^{\circ}$, mỗi khóm đập 2 đập, đếm số rầy trong khay

Công thức tính:

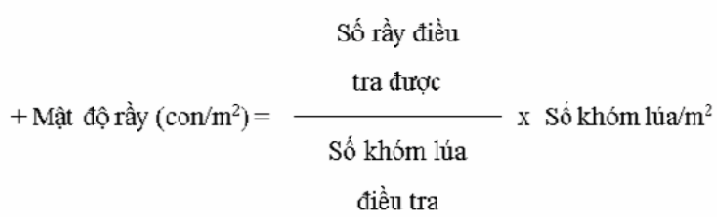

+ Hiệu lực thuốc được hiệu đính theo công thức Henderson - Tilton.

$$
H(\%)=1-\left(\frac{C_{b} \times T_{a}}{C_{a} \times T_{b}}\right) \times 100
$$

Trong đó:

- H: Là hiệu lực của thuốc tính theo phần trăm.

- Ca: là số lượng cá thể rầy sống ở công thức đối chứng sau xử lý.

- $\mathrm{Cb}$ : là số lượng cá thể rầy sống ở công thức đối chứng trước xử lý.

- Ta: là số lượng cá thể rầy sống ở công thức thí nghiệm sau xử lý.

- Tb: là số lượng cá thể rầy sống ở công thức thí nghiệm trước xử lý

* Đánh giá ảnh hưởng của thuốc với lúa 1,3,7,10 ngày sau xử lý theo phân cấp sau đây:

\begin{tabular}{|c|l|}
\hline $\begin{array}{c}\text { Cấp } \\
\text { độc }\end{array}$ & Triệu chứng nhiễm độc của cây trồng \\
\hline 1 & Cây chưa có biểu hiện nhiễm độc \\
\hline 2 & Ngộ độc nhẹ, sinh trưởng của cây giảm nhẹ \\
\hline 3 & Có triệu chứng ngộ độc nhẹ nhìn thấy bằng mắt \\
\hline
\end{tabular}




\begin{tabular}{|c|l|}
\hline 4 & $\begin{array}{l}\text { Triệu chứng ngộ độc nhưng chưa ảnh hưởng } \\
\text { đến năng suất }\end{array}$ \\
\hline 5 & $\begin{array}{l}\text { Cành lá biến màu hoặc cháy, thuốc gây ảnh } \\
\text { hưởng đến năng suất }\end{array}$ \\
\hline 6 & Thuốc làm giảm năng suất ít \\
\hline 7 & Thuốc gây ảnh hưởng nhiều đến năng suất \\
\hline 8 & Triệu chứng ngộ độc tăng dần tới làm chết cây \\
\hline 9 & Cây bị chết hoàn toàn \\
\hline
\end{tabular}

\subsection{Phuơng pháp xủ̉ lý số liệu}

Số liệu được xử lý bằng phần mềm Excel 2010.

\section{Kết quả nghiên cứu}

\subsection{Kết quả nghiên cứu diê̂n biến quần thể rầy} hại lúa năm 2014

a. Diễn biến mật độ quần thể rầy nâu

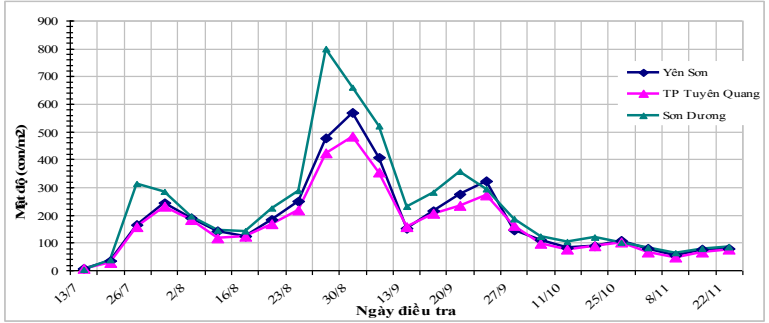

Hình 1: Diễn biến mật độ rầy nâu tì̀ tháng 7/2014 đến 12/2014

Qua hình 1 cho thấy: từ tháng 7-12 năm 2014 rầy nâu có 4 lứa, lứa gây hại nặng ứng với giai đoạn trỗ bông đến chín sáp từ cuối tháng 8 đến giữa tháng 9 . Mật độ rầy nâu cao nhất ở Sơn Dương là $800 \mathrm{con} / \mathrm{m}^{2}$ tiếp đến ở Yên Sơn $567 \mathrm{con} / \mathrm{m}^{2}$ và thành phố Tuyên Quang $482 \mathrm{con} / \mathrm{m}^{2}$.

b. Diễn biến mật độ rầy lưng trắng

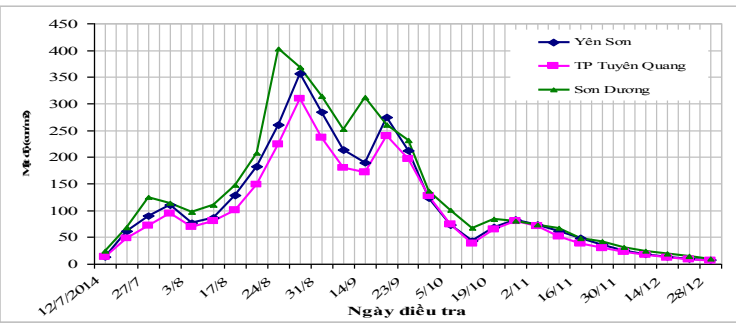

Hình 2: Diê̂n biến mật độ rầy lung trắng tù tháng 7/2014 đến tháng 12/2014

Rầy lưng trắng có 4 lứa. Từ cuối tháng 7 mật độ rầy lưng trắng bắt đầu tăng dần và đạt cao nhất vào cuối tháng 8 gây cháy rầy cục bộ vào đầu tháng 9 với mật độ phổ biến lần lượt là $403 \mathrm{con} / \mathrm{m}^{2}$ ở huyện Sơn Dương, tiếp đến 356 con $/ \mathrm{m}^{2}$ ở huyện Yên Sơn, và 310 $\mathrm{con} / \mathrm{m}^{2}$ thành phố, sau đó giảm dần.

3.2. Kết quả nghiên cúu diễn biến quần thể rầy hại lúa năm 2015

a. Diễn biến mật độ quần thể rầy nâu

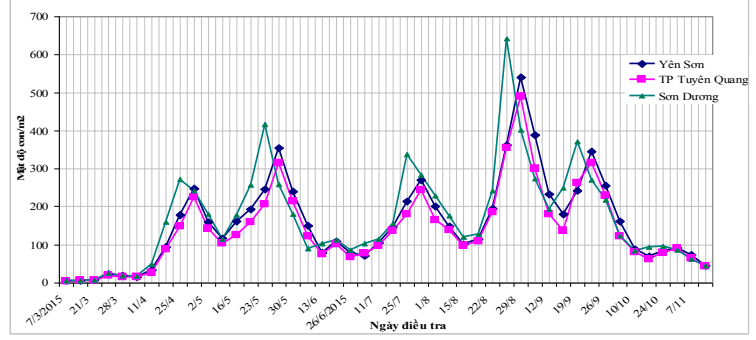

Hinh 3: Diễn biến mật độ rầy nâu năm 2015

Từ hình 3 cho thấy năm 2015 rầy nâu có 8 lứa. Vụ xuân rầy nâu có 3 lứa gây hại, Lứa 2 (giữa tháng 4) mật độ bắt đầu tăng, lứa 3 (giữa tháng 5 ) mật độ rầy nâu cao nhất (giai đoạn trỗ bông-chín sữa): Huyện Sơn Dương có mật độ phổ biến cao nhất là $418 \mathrm{con} / \mathrm{m}^{2}$ tiếp đến ở huyện Yên Sơn $355 \mathrm{con} / \mathrm{m}^{2}$ và thành phố Tuyên Quang $315 \mathrm{con} / \mathrm{m}^{2}$. Vụ mùa rầy nâu xuất hiện 4 lứa, lứa 4 (tháng 6) giai đoạn lúa hồi xanh - đẻ nhánh mật độ rầy thấp, lứa 5 mật độ tăng dần, lứa 6( cuối tháng 8- tháng 9) mật độ rầy đạt cao nhất: huyện Sơn Dương mật độ rầy phổ biến $642 \mathrm{con} / \mathrm{m}^{2}$ đạt cao nhất tiếp đến huyện Yên Sơn $540 \mathrm{con} / \mathrm{m}^{2}$ và thành phố Tuyên Quang $490 \mathrm{con} / \mathrm{m}^{2}$, lứa 7 gây hại trên trà muộn mật độ rầy giảm (giai đoạn chín - thu hoạch), lứa 8 rầy trú ngụ tại lúa chét, bờ cỏ và qua đông.

b. Diễn biến mật độ rầy lưng trắng

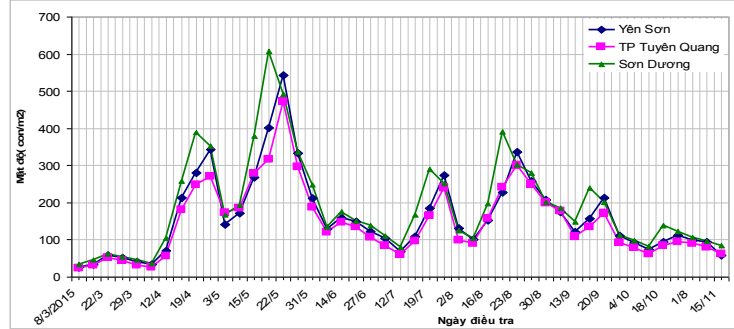

Hình 4: Diễn biến mật độ rầy lung trắng năm 2015

Nhận xét: Năm 2015 rầy lưng trắng xuất hiện 8 lứa: Vụ xuân có 3 lứa, tháng 3 (lứa 1 ) mật độ thấp, tháng 4 (lứa 2) mật độ tăng dần, cao nhất và gây hại nặng từ cuối đến giữa tháng 5 (lứa 3 ); mật độ rầy trung bình là $607 \mathrm{con} / \mathrm{m}^{2}$ ở Sơn Dương, $542 \mathrm{con} / \mathrm{m}^{2}$ ở Yên Sơn và $472 \mathrm{con} / \mathrm{m}^{2}$ thành phố Tuyên Quang sau đó giảm dần vào cuối vụ.

Vụ mùa: Rầy lưng trắng xuất hiện 5 lứa, tháng 7 (lứa 4) mật độ thấp rầy di chuyển từ xuân muộn sang mạ mùa sớm, lúa hồi xanh-đẻ nhánh, Tháng 8 (lứa 5) mật độ bắt đầu tăng, từ tháng 8 đến cuối tháng giữa tháng 9 ( lứa 6) đạt cao nhất, đây là lứa gây hại nặng, mật độ lần lượt 427 con $/ \mathrm{m}^{2}$ ở Sơn Dương; $373 \mathrm{con} / \mathrm{m}^{2}$ Yên Sơn và $331 \mathrm{con} / \mathrm{m}^{2}$ thành phố Tuyên Quang gây hại trên lúa mùa giai đoạn trỗ đến chín sữa; lứa 7 hại trên trà lúa mùa muộn mật độ giảm dần. 
3.3. Kết quả nghiên cứu diễn biến quần thể rầy hại lúa năm 2016

a. Diễn biến mật độ quần thể rầy nâu

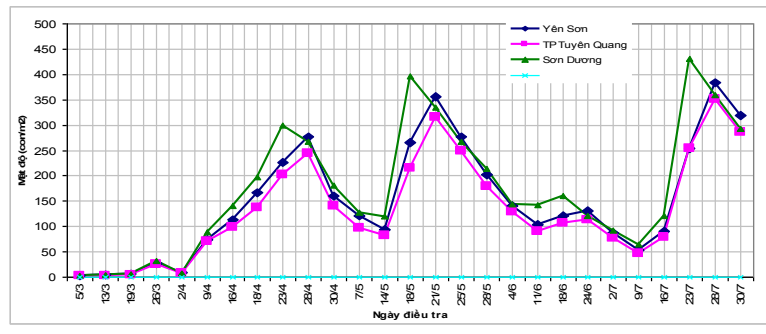

Hình 5: Diễn biến mật độ rầy nâu tù tháng 1/2016 đến tháng $8 / 2016$

Nhận xét: Vụ xuân 2016: Rầy nâu xuất hiện 3 lứa. Tháng 3 (lứa 1) rầy phát sinh mật độ thấp, sau đó tăng dần vào cuối tháng 4 (lứa 2 ) và đạt cao nhất vào giữa tháng 5 (lứa 3) giai đoạn lúa trỗ bông-chín sữa. Mật độ phổ biến tại huyện Sơn Dương đạt cao nhất là 396 con $/ \mathrm{m}^{2}$, tiếp đến huyện Yên Sơn $355 \mathrm{con} / \mathrm{m}^{2}$ và thành phố Tuyên Quang 316 con $/ \mathrm{m}^{2}$.

Rầy nâu (lứa 4) di chuyển từ vụ xuân sang vụ mùa trên lúa từ giai đoạn lúa hồi xanh mật độ rầy thấp nhất đầu tháng 7 , từ cuối tháng 7 rầy lứa 5 phát sinh với mật độ tăng dần lần lượt là $431 \mathrm{con} / \mathrm{m} 2$ ở Sơn Dương, $384 \mathrm{con} / \mathrm{m} 2$ ở Yên Sơn và $351 \mathrm{con} / \mathrm{m} 2$ thành phố Tuyên Quang. Rầy lứa 6 chúng tôi dự kiến phát sinh gây hại vào cuối tháng 8 trở đi mật độ phổ biến trên $500 \mathrm{con} / \mathrm{m} 2$

b. Diễn biến mật độ rầy lưng trắng

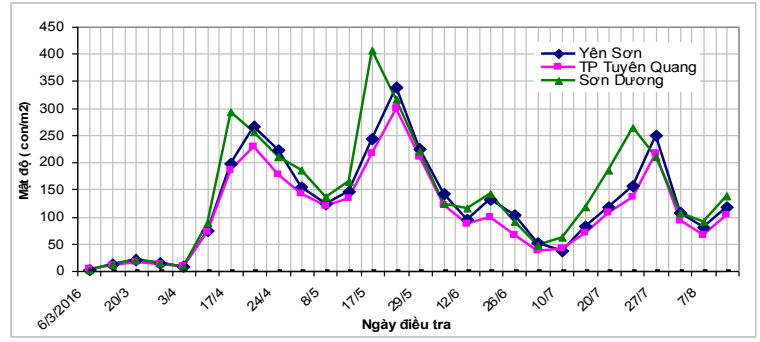

Hình 6: Diễn biến mật độ rầy lưng trắng tì tháng $01-8 / 2016$

- Vụ xuân: Có 3 lứa rầy lưng trắng gây hại, chúng xuất hiện muộn hơn so với cùng thời điểm năm trước, tháng 3 mật độ rầy lưng trắng đạt thấp nhất sau đó tăng dần từ giữa tháng 4 (lứa 2 ) và tăng cao nhất vào trung tuần tháng 5 (lứa 3) mật độ lần lượt là 356 ở Sơn Dương, $338 \mathrm{con} / \mathrm{m}^{2}$ ở Yên Sơn và $298 \mathrm{con} / \mathrm{m}^{2}$ thành phố Tuyên Quang, do mật độ thấp nên diện tích nhiễm vụ xuân năm 2016 cũng thấp.

Vụ mùa trên lúa rầy lưng trắng di chuyển từ vụ xuân giai đoạn hồi xanh mật độ rầy thấp nhất và mật độ rầy phát sinh tăng từ cuối tháng 7 (lứa 5) trở đi. Dự báo trong tháng 8 rầy lưng trắng sẽ phát sinh gây hại mật độ phổ biến trên 400 con $/ \mathrm{m}^{2}$

\section{Kết luận}

- Rầy nâu và rầy lưng trắng xuất hiện 8 lứa/ năm. Ở vụ xuân lứa 2,3, vụ mùa lứa 5,6 (giai đoạn lúa làm đòng đến chín sáp) và lứa 7 trên trà mùa muộn là các lứa có mật độ cao, thường gây hại nặng. Lứa 1,4 là các lứa đầu vụ mật độ thấp, chúng tích lũy để bùng phát mật độ cao cho lứa kế tiếp. Lứa 8 là lứa qua đông chúng chú ngụ chủ yếu trên lúa chét, bờ cỏ

- Các lứa rầy nâu và rầy lưng trắng xuất hiện trên đồng ruộng gần trùng khớp nhau rầy lưng trắng xuất hiện trước và đạt cao điểm trước rầy nâu khoảng 3-5 ngày, chúng cùng gây hại trên lúa. Đây chính là nguyên nhân gây hiện tượng cuối vụ trên đồng ruộng cùng lúc rầy có nhiều tuổi (gọi là gối lứa) gây khó khăn trong việc phòng trừ.

- Vào các lứa 2,5 tỷ lệ bắt gặp rầy lưng trắng cao hơn $(50-60 \%)$.

- Các lứa 3, 6, 7 rầy nâu và rầy lưng trắng cộng hưởng mật độ các lứa cao điểm đạt trung bình từ 800$1.200 \mathrm{con} / \mathrm{m}^{2}$ cục bộ có điểm lên trên 1.000 .000 con/m2 rất dễ gây cháy rầy cục bộ có khi trên diện rộng .

- Địa bàn huyện Sơn Dương các lứa rầy cũng thường ra trước 3-5 ngày so với huyện Yên Sơn, thành phố Tuyên Quang, (nguyên nhân do phần lớn diện gieo cấy lúa của huyện Sơn Dương được thực hiện tập chung vào các ngày đầu của trà lúa xuân chính vụ và trà lúa mùa sớm)

3.4. Thử nghiệm so sánh hiệu lụcc của nấm ký sinh Metarhizium anisopliae và thuốc bảo vệ thục vật có nguồn gốc sinh học trong phòng trù̀ rầy nâu và rầy lung trắng, đánh giá ảnh huởng của chế phẩm đến cây lúa.

Thực hiện theo quy chuẩn kỹ thuật quốc gia QCVN 01-29:2010/BNNPTPT về khảo nghiệm trên đồng ruộng hiệu lực của thuốc trừ rầy hại lúa: (bởi tính cộng hưởng gây hại cho nên chúng tôi đánh giá mật độ và hiệu lực chung cho cả rầy nâu và rầy lưng trắng sau đây gọi chung là rầy)

a. Thử nghiệm so sánh hiệu lực của nấm ký sinh Metarhizium anisopliae và thuốc bảo vệ thực vật có nguồn gốc sinh học trong phòng trừ rầy nâu và rầy lưng trắng

* Vụ mùa 2015

Diễn biến mật độ rầy ở các công thức thử nghiệm 


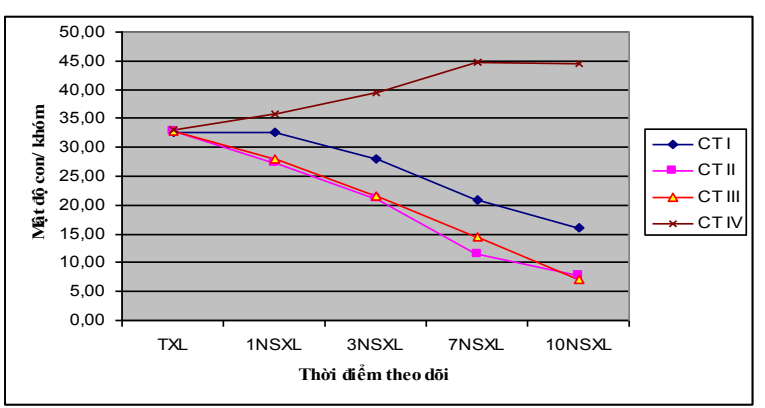

Hinh 7: Mật độ rầy các công thức thử nghiệm vu mùa 2014

Mật độ rầy tại công thức I, II, III ở 1, 3, 7,10 ngày sau xử lý đều thấp hơn so với công thức IV (đối chứng không xử lý thuốc). Mật độ rầy trên các công thức thí nghiệm có xử lý thuốc giảm dần theo các ngày sau xử lý, thấp nhất ở 10 ngày sau xử lý và đạt ở ngưỡng không gây thiệt hại cho cây lúa (dưới $20 \mathrm{con} / \mathrm{m}^{2}$ ). Mật độ rầy $\mathrm{CT}$ I giảm chậm hơn CT II và CT III ở tất cả các kỳ điều tra sau xử lý.

- Hiệu lực của các công thức thử nghiệm 1, 3, 7,10 ngày sau xử lý

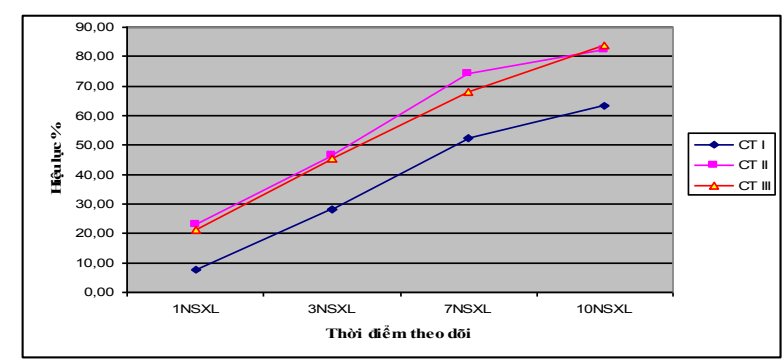

Hình 8: Hiệu lực trù rầy các công thức thử nghiệm vu mùa 2014

Ghi chú: NSXL: Ngày sau xủ lý.

Nhận xét: theo số liệu của hình 8 chúng tôi thấy hiệu lực của các thuốc khảo nghiệm đều có hiệu lực trừ rầy nâu, rầy lưng trắng hại lúa.

Hiệu lực trừ rầy hại lúa $10 \mathrm{NSXL}$ của $\mathrm{CT} \mathrm{I}, \mathrm{CT} \mathrm{II}$, CT III đạt cao nhất có hiệu lực lần lượt là $63,45 \%$; $81,50 \% ; 83,95 \%$

* Vụ xuân 2016:

- Diễn biến mật độ rầy trừ rầy ở các công thức thử nghiệm

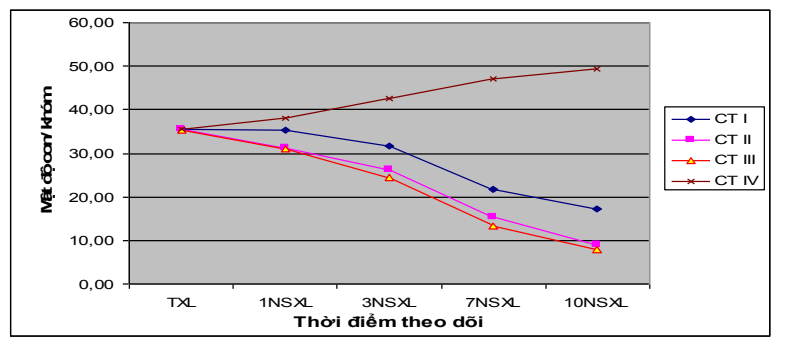

Hình 9: Mật độ rầy các công thức thư nghiệm vu xuân 2016
Mật độ rầy tại công thức I, II, III ở các thời điểm theo dõi 1, 3,7,10 sau xử lý đều thấp hơn so với công thức IV (đối chứng không xử lý), thấp nhất ở 10 ngày sau xử lý và đạt ở ngưỡng an toàn đối với cây lúa (dưới 20 con/khóm) . Mật độ rầy CT I giảm chậm hơn CT II và $\mathrm{CT}$ III ở các thời điểm theo dõi 1,3,7,10 ngày sau xử lý.

- Đánh giá về hiệu lực của các công thức thử nghiệm

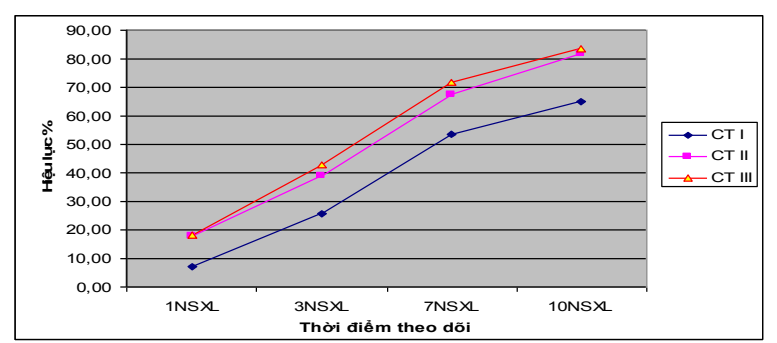

Hình 10: Hiệu lục trù rầy các công thức thư nghiệm vu xuân 2016

Ghi chú: TXL: truớc xủ lý, NSXL: ngày sau xư lý.

Theo số liệu của hình 10 chúng tôi thấy hiệu lực của các thuốc khảo nghiệm đều có hiệu lực trừ rầy lưng trắng hại lúa.

Hiệu lực của CT I, CT II, CT III đều có hiệu lực trừ rầy hại lúa tương tự như vụ mùa 2014 và lần lượt là $65,16 \% ; 81,88 \% ; 83,45 \%$.

Chế phẩm nấm M.anisopliae có hiệu lực trừ rầy vụ xuân 2016 (65,16\%) cao hơn vụ mùa 2014 (63,45\%).

Thời điểm 1, 3, 7,10 NSXL: Hiệu lực trừ rầy các công thức I, II, III đều tăng dần tuy nhiên công thức I hiệu lực tăng chậm hơn và đều thấp hơn công thức II, III.

- Ảnh hưởng của chế phẩm đối với cây trồng ở các ngày sau xử lý

Bảng 1: Ảnh huởng của chế phẩm đối với cây trồng ở các ngày sau xử lý

\begin{tabular}{|c|c|c|c|}
\hline \multirow{2}{*}{$\begin{array}{c}\text { Công } \\
\text { thức }\end{array}$} & \multicolumn{3}{|c|}{ Cấp hại } \\
\cline { 2 - 4 } & $\begin{array}{c}\mathbf{1} \\
\text { NSXL }\end{array}$ & $\begin{array}{c}\mathbf{3} \\
\text { NSXL }\end{array}$ & $\begin{array}{c}\mathbf{7} \\
\text { NSXL }\end{array}$ \\
\hline I & 1 & 1 & 1 \\
II & 1 & 1 & 1 \\
III & 1 & 1 & 1 \\
IV & 1 & 1 & 1 \\
\hline
\end{tabular}

Ghi chú: NSXL: Ngày sau xử lý.

Quan sát cả hai vụ cho thấy ảnh hưởng của chế phẩm nấm M.anisopliae (CT I) ) dùng ở liều lượng thử nghiệm $8 \mathrm{~kg}$ / ha và các công thức II, III ở 1, 3, 7 ngày sau xử lý đều lúa tương đương với CT II, III, IV không gây ảnh hưởng đến sự sinh trưởng và phát triển của cây lúa. 
Bảng 2: Diễn biến một số thiên địch chinh trong và ngoài mô hình vu mùa năm 2016

\begin{tabular}{|c|c|c|c|c|c|c|c|}
\hline \multirow{3}{*}{$\begin{array}{l}\text { Kỳ } \\
\text { điều } \\
\text { tra }\end{array}$} & \multirow{3}{*}{ GĐST } & \multicolumn{6}{|c|}{ Mật độ thiên địch (con/m²) } \\
\hline & & \multicolumn{3}{|c|}{$\begin{array}{c}\text { Ruộng sử dụng chế } \\
\text { phẩm Metarhizium } \\
\text { anisopliae }\end{array}$} & \multicolumn{3}{|c|}{$\begin{array}{l}\text { Ruộng không sử dụng } \\
\text { chê phâm Metarhizium } \\
\text { anisopliae }\end{array}$} \\
\hline & & $\begin{array}{c}\text { Nhện } \\
\text { băt } \\
\text { mổi } \\
\text { tổng } \\
\text { số }\end{array}$ & $\begin{array}{c}\text { Kiĉ́n } \\
\text { ba } \\
\text { khoang }\end{array}$ & $\begin{array}{c}\text { Bọ } \\
\text { xit } \\
\text { mù } \\
\text { xanh }\end{array}$ & $\begin{array}{c}\text { Nhện } \\
\text { bằ } \\
\text { mổi } \\
\text { tổng } \\
\text { số }\end{array}$ & $\begin{array}{c}\text { Kiến } \\
\text { ba } \\
\text { khoang }\end{array}$ & $\begin{array}{c}\text { Bo } \\
\text { xít } \\
\text { mù } \\
\text { xanh }\end{array}$ \\
\hline $21 / 6$ & Đẻ nhánh & 4,4 & 0,8 & 1,4 & 1,8 & 0,4 & 0 \\
\hline $28 / 6$ & Đẻ nhánh & 6,2 & 1,6 & 3,6 & 3,2 & 0,4 & 0 \\
\hline $5 / 7$ & Đlẻ rô & 14,3 & 1,6 & 1,4 & 4,2 & 1,2 & 0,4 \\
\hline $12 / 7$ & Cuối đẻ & 18,8 & 2,8 & 18 & 9,6 & 1,8 & 3,2 \\
\hline $19 / 7$ & Đứr.g cái & 16,2 & 4,8 & 11,2 & 4,8 & 3,2 & 6,8 \\
\hline $26 / 7$ & Làm Đòng & 14,8 & 3,2 & 16,8 & 6,4 & 2,4 & 8,6 \\
\hline $2 / 8$ & Làm Đờng & 17,4 & 2,4 & 18,2 & 11,8 & 2,6 & 11,4 \\
\hline $9 / 8$ & Đòng - trỗ & 19,6 & 4,8 & 20,2 & 14,4 & 3,6 & 16,4 \\
\hline $16 / 8$ & Phơi mảu & 12,2 & 2,2 & 30,4 & 10,2 & 1,8 & 22,4 \\
\hline $23 / 8$ & Ngậm sữa & 8,6 & 4,4 & 34,2 & 7,2 & 3,2 & 24,6 \\
\hline
\end{tabular}

Từ kết quả bảng 2 cho thấy mật độ thiên địch trong mô hình cao hơn ngoài mô hình và thành phần loài đa dạng hơn. Do ngoài mô hình sử dụng thuốc hoá học đã làm ảnh hưởng đến một số loài thiên địch trên đồng ruộng.

\section{Kết luận và đề nghị}

\subsection{Kết luận}

- Diễn biến quần thể rầy nâu, rầy lưng trắng: một năm xuất hiện 8 lứa: vụ xuân 3 lứa, vụ mùa 5 lứa, các lứa rầy nâu và rầy lưng trắng gần trùng khớp. Trong một lứa: rầy lưng trắng xuất hiện trước rầy nâu 3-5 ngày, nên giữa các lứa rầy có sự gối nhau, do có hiện tượng rầy mới nở của cuối lứa trước sẽ trùng với rầy nở trước của lứa sau, sẽ làm kéo dài thời gian phòng trừ. Các lứa 2,3 gây hại nặng vào các thời điểm cuối tháng 4,5 ; lứa $5,6,7$ gây hại gây hại nặng vào các thời điểm tháng 8,9 ứng với giai đoạn lúa trổ bông chín sữa. Lứa 2 và 5,6 tỷ lệ bắt gặp rầy lưng trắng lớn hơn rầy nâu, các lứa còn lại tỷ lệ bắt gặp rầy nâu lớn hơn rầy lưng trắng. Lứa 1,4 rầy chuyển vụ mật độ thấp, lứa 8 qua đông thường cư trú trên các ký chủ phụ, lúa chét mật độ thấp.

- Chế phẩm M.anisopliae ở liều lượng $8 \mathrm{~kg} / \mathrm{ha}$ có hiệu lực trừ rầy nâu, rầy lưng trắng hại lúa (hiệu lực 10 ngày sau xử lý đạt từ đến 61,68-65,16\% \%), không gây ảnh hưởng đến sự sinh trưởng và phát triển của cây lúa.

- Mô hình tổng hợp phòng trừ rầy nâu và rầy lưng trắng có sử dụng chế phẩm nấm M.anisopliae bảo vệ năng suất, sản lượng lúa, tạo ra sản phẩm an toàn, bảo vệ môi trường và sức khoẻ cộng đồng. Ngoài ra còn bảo vệ thiên địch trên đồng ruộng, cân bằng hệ sinh thái.

\section{2. Đề nghị}

- Căn cứ kết quả nghiên cứu về diễn biễn quần thể rầy nâu, rầy lưng trắng đề nghị được lồng nghép với các chương trình trình tập huấn khuyến nông để tuyên truyền cho người nông dân trồng lúa ở Tuyên Quang, nhận biết được thành phần rầy nâu, rầy lưng trắng, diễn biến quần thể và ứng dụng trong phòng trừ rầy hiệu quả, an toàn.

- Mô hình phòng trừ tổng hợp rầy nâu và rầy lưng trắng có sử dụng chế phẩm nấm M.anisopliae dễ ứng dụng, có hiệu quả cao, giảm ô nhiễm môi trường. Đề nghị được tuyên truyền, khuyến cáo cho các hộ nông dân nhân rộng nhiều điểm và diện tích ứng dụng chế phẩm nấm xanh $M$. anisopliae trong phòng trừ rầy nâu, rầy lưng trắng.

\section{TÀI LIỆU THAM KHẢO}

1. Cục BVTV: Báo cáo tổng kết công tác BVTV các tỉnh phía Bắc năm 2013,2014,2015

2. Nguyễn Thị Lộc, và cộng sự (2002), “Ảnh hưởng của nấm trắng và nấm xanh đối với một số thiên địch của sâu hại lúa”. Tạp chí Nông nghiệp và Phát triển Nông thôn, Số 6-2002

3. Nguyễn Thị Lộc và cộng sự (2002), Nghiên cúu, sản xuất và ưng dụng hai chế phẩm sinh học để quản lý các loài sâu hại lúa, Viện lúa ĐBSCL

4. Phạm Thị Thùy và cộng sự (1996), Nghiên cúu công nghệ sản xuất và ứng dụng chế phẩm nấm Beauveria và Metarhizium để phòng trù một số sâu hại cây trồng (1991- 1995), Tuyển tập công trình nghiên cứu bảo vệ thực vật, 1990- 1995. NXB Nông nghiệp, Hà Nội

5. Nguyễn Ngọc Tú, Nguyễn Cửu Thị Hương Giang (1997), Bảo vệ cây trồng tù các chế phẩm tù vi nấm, NXB Nông nghiệp TP. Hồ Chí Minh

6. Viện Bảo vệ thực vật (2001), Nghiên cúu áp dụng công nghệ vi sinh (vi khuẩn, vi nấm, virut) để sản xuất chế phẩm sinh họ BVTV trong phòng trù sâu hại cây trồng, Báo cáo tổng kết đề tài khoa học cấp nhà nước KHCN.02.07B giai đoạn 1996-2000

7. Viện Bảo vệ thực vật đã nghiên cứu và phân lập nấm Metarhizium anisopliae ký sinh trên các loại sâu hại cây trồng như trên rầy nâu hại lúa, bọ cánh cứng hại dừa, bọ hung hại mía, châu chấu hại ngô, mía và mối đất hại cây trồng Năm 1996

8. Hall F.R and Menn J.J (1999), BiopesticidesUse and delivery, Humana Press Inc 
9. Milner (1994) Biological control of termites: results and experiences whinin a CSIRO project in australia. Biocontrol Science and Technology
10. Mendoca A.F (1992), Mass production, application and fomulation of Metarhizium anisopliae for control of sugarcane froghopper, Biological control of locust and grasshopper

\section{Research and application, using parasitic fungus Metarhizium anisopliae to control brown backed rice plant hopper and white backed rice plant hopper in Tuyen Quang}

Pham Thi Mai Trang, Nguyen Thi Hoai Anh, Nguyen Thi Thu Hien

\section{Article info}

Recieved:

$15 / 5 / 2019$

Accepted:

$10 / 6 / 2019$

Keywords:

Metarhizium anisopliae;

Metarhizium sp; brown

planhopper; white

backed planhopper;

nivaparvata lugens

Stah; sogatella

furcifera.

\begin{abstract}
Brown planhopper and white backed planhopper are considered one of the main pests in rice in the world in general and Vietnam in particular. Planhopper not only directly damage quality and quantitive of rice but also a medium for transmitting disease-causing viruses in rice. Therefore, in order to control planhopper, farmers have used a lot of chemical drugs (pesticides). However, these pesticides are often highly toxic and slow to decompose, which can keep long-lasting effects in products. In order to gradually replace the use of chemical drugs in agricultural production, scientists have recently succeeded in using Metarhizium anisopliae in the prevention the insects in general and the planhopper in particular. Test results in Tuyen Quang in 2015,2016 showed that: Metarhizium anisopliae in $8 \mathrm{~kg} /$ ha dosage was effective e for brown planhopper and white backed planhopper, effective 10 days after treatment reached from $61,68-65.16 \% \%$. It does not affect the growth, development, productivity and quality of rice plants and it does not affect the ecological environment.
\end{abstract}

